Research Article

\title{
High interpopulation homogeneity in Central Argentina as assessed by Ancestry Informative Markers (AIMs)
}

Angelina García ${ }^{1,2}$, Darío A. Dermarchi ${ }^{1,2}$, Luciana Tovo-Rodrigues ${ }^{3}$, Maia Pauro ${ }^{1,2}$, Sidia M. Callegari-Jacques ${ }^{3}$, Francisco M. Salzano ${ }^{3}$ and Mara H. Hutz ${ }^{3}$

${ }^{1}$ Instituto de Antropología de Córdoba, Consejo Nacional de Investigaciones Científicas y Técnicas, Universidad Nacional de Córdoba, Córdoba, Argentina.

${ }^{2}$ Facultad de Filosofía y Humanidades, Universidad Nacional de Córdoba, Córdoba, Argentina.

${ }^{3}$ Departamento de Genética, Instituto de Biociências, Universidade Federal do Rio Grande do Sul,

Porto Alegre, RS, Brazil.

\begin{abstract}
The population of Argentina has already been studied with regard to several genetic markers, but much more data are needed for the appropriate definition of its genetic profile. This study aimed at investigating the admixture patterns and genetic structure in Central Argentina, using biparental markers and comparing the results with those previously obtained by us with mitochondrial DNA (mtDNA) in the same samples. A total of 521 healthy unrelated individuals living in 13 villages of the Córdoba and San Luis provinces were tested. The individuals were genotyped for ten autosomal ancestry informative markers (AIMs). Allele frequencies were compared with those of African, European and Native American populations, chosen to represent parental contributions. The AIM estimates indicated a greater influence of the Native American ancestry as compared to previous studies in the same or other Argentinean regions, but smaller than that observed with the mtDNA tests. These differences can be explained, respectively, by different genetic contributions between rural and urban areas, and asymmetric gene flow occurred in the past. But a most unexpected finding was the marked interpopulation genetic homogeneity found in villages located in diverse geographic environments across a wide territory, suggesting considerable gene flow.
\end{abstract}

Keywords: AIMs, Córdoba, San Luis, migration, population structure.

Received: September 10, 2014; Accepted: March 25, 2015.

\section{Introduction}

The population of Argentina, like those of other Latin American countries, has diverse ethnic origins, determined by immigration from Europe (mainly Spain and Italy) and Africa (people brought by force as slaves), and the subsequent cultural and genetic exchanges which took place between these populations and Native Americans (Sans, 2000). The arrival of the first Spaniards, five centuries ago, initiated the first of the two main periods in the immigration process: (a) the first half of the $16^{\text {th }}$ century, characterized by the arrival of Europeans to colonize the territory, and the traffic of African slaves, to guarantee the exploitation of resources; and (b) the second half of the $19^{\text {th }}$ and early $20^{\text {th }}$ century, marked by a population expansion resulting from massive European immigration, favored by a process of economic internationalization (Pellegrino, 2002). More recently, immigration originates mainly from other countries

Send correspondence to Angelina García. Instituto de Antropología de Córdoba, Consejo Nacional de Investigaciones Científicas y Técnicas, Universidad Nacional de Córdoba, Hipólito Yrigoyen 174, 5000 Córdoba, Argentina. E-mail: angelina13g@gmail.com. of the American Southern Cone (Albarracín, 2005). All these people merged in a complex process, evidenced by the heterogeneous degrees of admixture observed in different regions of the country. Two aspects can be considered here: the relative contribution of the different parental groups and the migration from the rural areas of northern Argentina to the industrialized cities of the fertile Pampean region (Elizalde and Macció, 1990).

The degree of genetic admixture in Argentinean urban populations has been estimated by several studies, using blood groups (Avena et al., 1999, 2001), GM/KM allotypes and mitochondrial DNA (Avena et al., 2006, 2009), uniparental molecular markers (mtDNA and Ychromosome) (Corach et al., 2001; Salas et al., 2008; Bobillo et al., 2010), autosomal polymorphisms (Sala et al., 1998; Demarchi et al., 2005; Seldin et al., 2007), and studies combining uniparental and biparental markers in the same individuals (Martínez-Marignac et al., 2004; Corach et al., 2010). As observed by Salzano (2002), although much information is already available, it is highly heteroge- 
neous regarding both populations and types of genetic systems investigated.

An increasing number of publications have assessed the composition of human populations using ancestryinformative markers (AIMs) to estimate admixture and to identify population substructure (Mao et al., 2007; Price et al., 2007; Seldin et al., 2007; Kosoy et al., 2009; Santos et al., 2010; Amorim et al., 2011; Avena et al., 2012). AIMs consist of single nucleotide polymorphisms (SNPs) distributed throughout the genome which show large differences in allele frequencies between populations of distinct geographic origins, thus distinguishing particular ancestral groups that correspond to continental populations. AIMs have been used previously for estimating admixture in a few Argentinean populations (Martínez-Marignac et al., 2004; Seldin et al., 2007; Corach et al., 2010; Avena et al., 2012).

The center of Argentina, particularly the provinces of Córdoba and San Luis, is a particularly interesting region because its crossroads geographic location can help to understand population forming processes in the southernmost region of South America. Besides, this region is crossed in the south/north direction by the old "Camino Real", one of the main roads used by Spaniards, African slaves and $\mathrm{Na}-$ tive Americans in colonial times, a place of cultural and demographic exchanes. During the colonial period (from the 16 th to the early 19th century), the province of Córdoba played a major role in the distribution of slaves and merchandise to other geographic regions of the Southern Cone (Rufer, 2004; UNESCO, 2005; Grosso, 2008).

In this study, we investigated the genetic variability and relative parental contributions in 13 villages across the provinces of Córdoba and San Luis (Argentina), using biparental markers, represented by a set of 10 AIMs. The main objective was to examine admixture patterns and genetic structure in different population of central Argentina, in an attempt to understand the population history of this region, and to compare the results with those observed in other regions of the country and elsewhere. We also compared the results obtained in this study with previous results obtained by our group using mtDNA markers in the same samples.

\section{Materials and Methods}

\section{Population samples}

A total of 521 samples from healthy, unrelated individuals were collected in nine villages of the Córdoba province $(\mathrm{N}=381)$ and four of the San Luis province $(\mathrm{N}=140)$. The sample sizes for each locality are presented in Table 3.

Figure 1 shows the map of the area with the sampling places. The study area is located in the southern part of the Argentinean Sierras Pampeanas, at latitudes $30^{\circ} \mathrm{S}$ to $33^{\circ} \mathrm{S}$ and longitudes $62^{\circ} \mathrm{W}$ to $65^{\circ} \mathrm{W}$, covering the mountain ranges of the provinces of Córdoba and San Luis, as well as their eastern neighboring plains.

All the participants were informed of the objectives of this nonprofit scientific investigation and signed a written informed consent. The information obtained in the field regarding the birthplaces of the participants, their parents and grandparents indicated low to moderate mobility of the inhabitants of these villages, limited to their region of origin. Thus, we assume that the sample represents fairly well the actual population structure of the area.

\section{Genotyping}

Genomic DNA was extracted from cheek swabs, using the IsoQuick Kit (Orca Research, Bothell, Washington). Genotyping for ACKR1, WI14319, CKM, OCA2, TYR, WI11909, CYP3A4, TNFRSF1A and IL2 SNPs was performed with validated TaqMan genotyping assays (Real Time PCR, Applied Biosystems, California, USA) according to the manufacturer's protocol. PV92 was tested by standard PCR, according to Batzer et al. (1994). PV92 Alu insertion genotypes were directly determined in $2 \%$ agarose gel with ethidium bromide staining. Information from the National Center for Biotechnology Information (NCBI), reference number and chromosome location of the 10 markers are presented in Table 1. One measure of the informativeness of such markers is the allele frequency differential $(\delta)$, which is the absolute value of the difference of a particular allele between parental populations (Chakraborty and Weiss, 1988; Dean et al., 1994). We selected

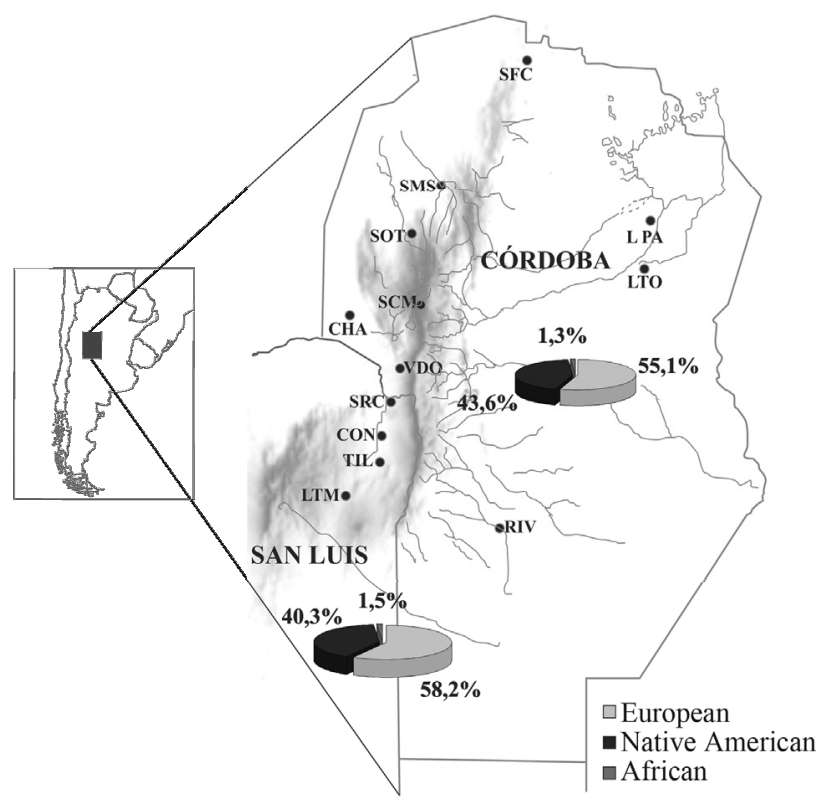

Figure 1 - Approximate area of the Sierras Centrales region of Argentina and sampling locations, with ancestry contributions estimated based on the populations of Córdoba and San Luis. SMS, San Marcos Sierras; LTO, La Tordilla; SFC, San Francisco del Chañar; SCM, San Carlos Minas; LPA, La Para; VDO, Villa Dolores; SOT, Villa de Soto; CHA, Chancaní; RIV, Río Cuarto; TIL, Tilisarao; SRC, Santa Rosa de Conlara; CON, Concarán; LTM, La Toma. 
Table 1 - Ancestry Informative Markers used in this study.

\begin{tabular}{lccc}
\hline Marker & $\begin{array}{c}\text { Molecular } \\
\text { technique }^{\mathrm{a}}\end{array}$ & $\begin{array}{c}\text { Reference } \\
\text { number (rs) }\end{array}$ & $\begin{array}{c}\text { Chromosome } \\
\text { location }\end{array}$ \\
\hline ACKR1 & RT & 2814778 & $1 \mathrm{q} 23.2$ \\
WI14319 & RT & 2862 & $15 \mathrm{q} 14$ \\
CKM & RT & 4884 & $19 \mathrm{q} 13.32$ \\
OCA2 & RT & 1800404 & $15 \mathrm{q} 13.1$ \\
TYR & RT & 1042602 & $11 \mathrm{q} 14.3$ \\
WI11909 & RT & 2695 & $9 \mathrm{q} 21.31$ \\
CYP3A4 & RT & 2740574 & $7 \mathrm{q} 22.1$ \\
TNFRSF1A & RT & 4149622 & $12 \mathrm{p} 13.31$ \\
IL2 & RT & 2069762 & $4 \mathrm{q} 27$ \\
PV92 & PCR & 3138523 & $16 \mathrm{q} 23.3$ \\
\hline
\end{tabular}

${ }^{a}$ RT: Real Time; PCR: standard PCR.

${ }^{b}$ rs: Reference Number retrieved from dbSNP build 138, available on the human genome assembly (GRCh37/hg19).

SNPs with large frequency differences between continental populations (African, European, and Native American) (Shriver et al., 2003; Yang et al., 2005; Zembrzuski et al., 2010). Genetic markers with the largest genetic distances between parental populations are the best candidates for population differentiation (Shriver et al., 2004). The putative parental population frequencies were estimated using previously reported genotypes, recently updated, retrieved from different databases (Table 2).

\section{Statistical analysis}

Allele frequency estimates were obtained by direct gene count. Tests of observed and expected heterozygosity, Hardy-Weinberg equilibrium (HWE), and Analysis of Molecular Variance (AMOVA) at two hierarchical levels were carried out using the Arlequin v. 3.1 software package (Excoffier et al., 2005). The HWE tests were performed using 100,000 steps in the Markov chain, setting the significance level at $\mathrm{p}<0.05$. The P-values for $\mathrm{F}_{\mathrm{ST}}$ and AMOVA estimates were obtained after 10,100 permutations, employing the same significance level. Chakrabortys method for the estimation of admixture proportions by means of gene identity (Chakraborty, 1985) was performed using the ADMIX95 program. The fit of this model can be evaluated in terms of R-square, which is an expected multiple correlation coefficient of the allele frequencies in a hybrid population and those of the parental populations, under the assumption of a true admixture model (Chakraborty, 1986). To evaluate the statistical significance of genetic affinities among populations based on AIMs frequencies, principal components analysis was used.

\section{Results}

\section{Allele frequencies and HWE}

The allele frequencies of the 10 biallelic AIMs observed in the pooled samples of Córdoba and San Luis and in the parental stocks (Europeans, Native Americans, and Africans) are presented in Table 2. Most of the studied markers were in Hardy-Weinberg equilibrium, with the exception of CKM ( $p=0.027)$, and WI-11909 $(p=0.011)$ in Córdoba, and ACKR1 ( $\mathrm{p}=0.031)$ in San Luis. These marginal deviations are most likely due to sampling errors.

\section{Population structure}

Heterozygosity was similar in the 13 subpopulations, ranging from 0.322 in San Carlos Mina to 0.405 in La Tordilla (Table 3). The intergroup genetic differences were not significant $\left(\mathrm{F}_{\mathrm{ST}}=0.004, \mathrm{p}=0.054\right)$. The AMOVA re-

Table 2 - Summary of 10 AIM allele frequencies in the provinces of Córdoba and San Luis, and in the European, Native American and African parental stocks.

\begin{tabular}{|c|c|c|c|c|c|c|}
\hline \multirow[t]{2}{*}{ Marker } & \multirow[t]{2}{*}{ Córdoba } & \multirow[t]{2}{*}{ San Luis } & \multirow[t]{2}{*}{$\mathrm{N}$} & \multicolumn{3}{|c|}{ Parental populations $\mathrm{s}^{\mathrm{a}}$} \\
\hline & & & & European & Native American & African \\
\hline $\mathrm{ACKR} 1 * \mathrm{~T}$ & 0.962 & 0.950 & 487 & 0.995 & 0.994 & 0.021 \\
\hline WI $14319 * \mathrm{C}$ & 0.389 & 0.350 & 500 & 0.231 & 0.716 & 0.352 \\
\hline $\mathrm{CKM}{ }^{*} \mathrm{~T}$ & 0.495 & 0.439 & 509 & 0.289 & 0.860 & 0.167 \\
\hline OCA $2 * A$ & 0.580 & 0.611 & 514 & 0.753 & 0.434 & 0.127 \\
\hline TYR*A & 0.311 & 0.277 & 512 & 0.465 & 0.059 & 0.002 \\
\hline WI11909*G & 0.475 & 0.507 & 518 & 0.774 & 0.186 & 0.815 \\
\hline CYP3A4*A & 0.898 & 0.918 & 519 & 0.967 & 0.959 & 0.211 \\
\hline TNFRSF1A $* G^{b}$ & 0.105 & 0.093 & 506 & 0.000 & 0.050 & 0.650 \\
\hline IL $2 * \mathrm{G}^{\mathrm{b}}$ & 0.656 & 0.668 & 508 & 0.232 & 0.170 & 0.000 \\
\hline PV92*1 & 0.445 & 0.496 & 427 & 0.161 & 0.781 & 0.210 \\
\hline
\end{tabular}

${ }^{a}$ The frequencies were retrieved from the dbSNP NCBI. (http://www.ncbi.nlm.nih.gov/SNP/), under the submitter handle PSU-ANTH, HapMap, and ALFRED database.

${ }^{\mathrm{b}}$ Data from Zembrzuski et al. (2010). 
Table 3 - Percentage of continental parental contribution for autosomal AIMs (SD, Standard Deviation) and mitochondrial haplogroups, and heterozygosity values for 13 villages of central Argentina.

\begin{tabular}{|c|c|c|c|c|c|c|c|c|}
\hline \multirow{3}{*}{ Localities $^{\mathrm{a}}$} & \multirow[b]{3}{*}{$\mathrm{N}$} & \multicolumn{6}{|c|}{$\%$ parental contribution } & \multirow[t]{3}{*}{ Heterozygosity } \\
\hline & & \multicolumn{2}{|c|}{ European } & \multicolumn{2}{|c|}{ Native American } & \multicolumn{2}{|c|}{ African } & \\
\hline & & AIMs & $\mathrm{mtDNA}^{\mathrm{b}}$ & AIMs & $\mathrm{mtDNA}^{\mathrm{b}}$ & AIMs & $\mathrm{mtDNA}^{\mathrm{b}}$ & \\
\hline Villa de Soto ${ }^{1}$ & 58 & $66.7(3.6)$ & 13 & $32.6(2.9)$ & 77 & $0.7(3.5)$ & 10 & $0.385 \pm 0.257$ \\
\hline San Carlos Mina ${ }^{1}$ & 17 & $67.8(6.1)$ & 16 & $38.2(5.1)$ & 79 & $-6.0(4.6)$ & 5 & $0.322 \pm 0.230$ \\
\hline Villa Dolores ${ }^{1}$ & 23 & $49.9(5.0)$ & 12 & $49.9(3.2)$ & 82 & $0.2(4.1)$ & 6 & $0.370 \pm 0.215$ \\
\hline Chancaní $^{1}$ & 24 & $55.0(5.7)$ & 13 & $49.0(3.9)$ & 73 & $-4.0(4.4)$ & 14 & $0.348 \pm 0.203$ \\
\hline San Marcos Sierras ${ }^{1}$ & 33 & $49.1(3.8)$ & 11 & $48.4(2.6)$ & 75 & $2.5(3.4)$ & 14 & $0.375 \pm 0.239$ \\
\hline San Fco. del Chañar ${ }^{1}$ & 52 & 48.7. (4.4) & 4 & $46.4(2.7)$ & 84 & $4.9(4.1)$ & 12 & $0.365 \pm 0.205$ \\
\hline Río Cuarto $^{2}$ & 85 & $56.7(4.6)$ & 26 & $43.9(2.6)$ & 74 & $-0.6(3.8)$ & 0 & $0.403 \pm 0.266$ \\
\hline La Tordilla ${ }^{2}$ & 24 & $56.6(2.2)$ & 27 & $39.8(1.7)$ & 62 & $3.6(2.2)$ & 11 & $0.405 \pm 0.234$ \\
\hline $\mathrm{La} \mathrm{Para}^{2}$ & 65 & $49.5(4.9)$ & 18 & $47.5(3.3)$ & 76 & $3.0(3.9)$ & 6 & $0.340 \pm 0.209$ \\
\hline Córdoba Total & 381 & $55.1(4.2)$ & 16 & $43.6(2.5)$ & 76 & $1.3(3.7)$ & 8 & \\
\hline Santa Rosa de Conlara ${ }^{1}$ & 33 & $52.1(4.9)$ & 6 & $44.8(3.6)$ & 94 & $3.1(2.9)$ & 0 & $0.378 \pm 0.213$ \\
\hline Concarán ${ }^{1}$ & 29 & $61.9(3.7)$ & 14 & $37.2(2.4)$ & 81 & $0.9(2.4)$ & 5 & $0.374 \pm 0.212$ \\
\hline Tilisarao $^{1}$ & 30 & $56.8(2.8)$ & 4 & $39.7(2.0)$ & 92 & $3.5(2.6)$ & 4 & $0.335 \pm 0.196$ \\
\hline La Toma $^{1}$ & 48 & $50.8(6.5)$ & 13 & $54.0(4.7)$ & 84 & $-4.8(4.4)$ & 3 & $0.350 \pm 0.202$ \\
\hline San Luis Total & 140 & $58.2(3.8)$ & 11 & $40.3(2.5)$ & 88 & $1.5(3.4)$ & 3 & \\
\hline
\end{tabular}

${ }^{\mathrm{a}}$ Geographic regions: ${ }^{1}$ Sierras; ${ }^{2}$ Plains.

${ }^{\mathrm{b}}$ Pauro et al. (2001).

sults are presented in Table 4. No statistically significant genetic differences were found between provinces (Córdoba vs. San Luis) or geographic regions (Plains vs. Mountains); the interpopulation variation between subpopulations within each of these units was only marginally significant.

\section{Admixture estimates}

Admixture analysis using the 10 AIMs was performed to estimate the mean contributions of European, African, and Native American parental populations to the contemporary population. The tri-hybrid admixture model showed to be adequate for estimating parental contributions in all populations $(\mathrm{R}$-square $=0.991)$. The results are shown in Table 3. The European component was the most frequently represented in all subpopulations, except in Villa Dolores (Córdoba) and La Toma (San Luis), where the Native American component was of the same or greater magnitude. Admixture estimation by province showed a slightly higher proportion of European ancestry in San Luis than in Córdoba $(0.582 \pm 0.038$ vs. $0.551 \pm 0.042)$, whereas in Córdoba there was a relatively higher proportion of Native American ancestry than in San Luis $(0.435 \pm 0.025 v s$. $0.403 \pm 0.025)$. The African component was negligible in all the subpopulations investigated. There were differences when AIMs and mtDNA were considered, with the latter consistently showing higher Native American and African ancestries.

Table 4 - Analysis of the molecular variance between provinces (Córdoba vs. San Luis) and between geographic regions (Sierras vs. Plains) in central Argentina based on the frequencies of 10 AIMs. La Tordilla, Río Cuarto, and La Para are plain populations, while the other sampling sites are located in the sierras region.

\begin{tabular}{lccc}
\hline Source of variation & Degrees of freedom & Variance component & Percentage of variation \\
\hline Between provinces & 1 & -0.002 & $-0.11(\mathrm{p}=0.786)$ \\
Among populations within provinces & 11 & 0.006 & $0.42(\mathrm{p}=0.043)$ \\
Within populations & 1029 & 1.558 & $99.69(\mathrm{p}=0.049)$ \\
Between geographic regions & 1 & -0.001 & $-0.06(\mathrm{p}=0.658)$ \\
Among populations within geographic regions & 11 & 0.006 & $0.40(\mathrm{p}=0.051)$ \\
Within populations & 1029 & 1.558 & $99.66(\mathrm{p}=0.064)$ \\
\hline
\end{tabular}


In the principal component analysis (Figure 2), the subpopulations of Córdoba and San Luis appeared close to each other, with the villages showing no clear distribution pattern. This compact cluster falls halfway between Native Americans and Europeans, but is closer to the latter and very distant from Africans.

\section{Discussion}

The aim of this study was to investigate the genetic structure and admixture patterns in populations living across central Argentina, using biparentally inherited ancestry informative markers (AIMs). The low intergroup differentiation $\left(\mathrm{F}_{\mathrm{ST}}=0.004, \mathrm{p}=0.054\right)$ suggests sustained gene flow among populations and absence of geographic or ethnic barriers. In previous studies, we investigated the distribution of mtDNA markers in the same villages. Despite having different histories and being located in diverse geographic environments across a wide territory, a surprisingly low genetic variation among villages was observed (García and Demarchi, 2009; Pauro et al., 2010, and García A, 2011, Doctoral Thesis, Facultad de Ciencias Exactas, Físicas y Naturales, Universidad Nacional de Córdoba), as confirmed by our results in the present study. Previous studies of human groups from central Argentina have proposed the existence of regionalism, in an attempt to demarcate differential geographic areas whose boundaries were dependent on the particularities or traits that circumscribed each of these studies. For example, the existence of different evolutionary histories between the mountains and plains populations was proposed by Serrano (1945). However, in this study we did not find statistically significant differences when geographic regions (plains vs. sierras) or provinces (Córdoba vs. San Luis) were compared, despite

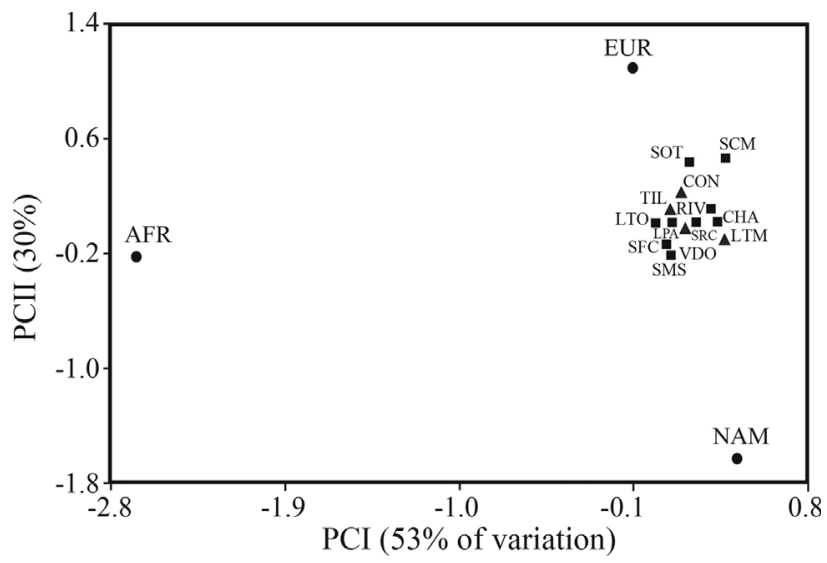

Figure 2 - Principal Component Analysis based on the frequencies of 10 AIMs in 13 populations of central Argentina and 3 parental stocks. NAM (Native American); AFR (African), EUR (European). SMS, San Marcos Sierras; LTO, La Tordilla; SFC, San Francisco del Chañar; SCM, San Carlos Minas; LPA, La Para; VDO, Villa Dolores; SOT, Villa de Soto; CHA, Chancaní; RIV, Río Cuarto; TIL, Tilisarao; SRC, Santa Rosa de Conlara; CON, Concarán; LTM, La Toma. Squares and triangles represent sites of Córdoba and San Luis, respectively. the innumerable succession of historical demographic events that occurred in ancient times and, above all, after the Conquest (aggregations, dismemberments, and transfers). These results suggest a geographic and temporal continuity of the gene pool of the population that inhabited the central region of Argentina.

The two parental populations that contributed most to the gene pool of the populations of Córdoba and San Luis are the European (55\% and 58\%) and the Native American (44\% and $40 \%$ ) sets. These values are different from those obtained by Seldin et al. (2007) in the province of Córdoba using 78 AIMs (respectively $77.2 \%$ and $22.8 \%$ ), while the African component is virtually absent in both samples.

In previous studies that focused on genetic admixture using AIM markers, differential ancestral contributions were observed in different regions of Argentina. In general, much lower Native American and much higher European ancestry proportions were detected in most of these studies, as compared to what we observed here. For instance, Corach et al. (2010) and Avena et al. (2012) found that, in the Buenos Aires population, the average European and Native American ancestry components were, respectively, $78.6 \%$ and $17.3 \%$, and $65 \%$ and $31 \%$. A similar picture was found by Martínez-Marignac et al. (2004) for the relative European and Native American contributions to the gene pool of La Plata, namely $67.6 \%$, and $25.9 \%$, respectively. Based on the ABO system phenotypes of population samples from the six provinces of northwest Argentina (NWA) (Jujuy, Salta, Tucuman, Catamarca, La Rioja, and Santiago del Estero), Morales et al. (2000) found a Native American component of over $60 \%$ in the provinces of Jujuy and Salta, while the Spanish (European) contribution predominated in Catamarca, La Rioja and Tucumán. An African component of over 20\% was found in Santiago del Estero, Tucumán, and Catamarca. On the other hand, Alfaro et al. (2005), based on HLA-A and HLA-B allele frequencies of the same NWA population samples, observed, for the whole region, $50 \%$ of Spanish, $40 \%$ of Native American and 10\% of African contributions. In contrast with our findings, they found a marked inter-population heterogeneity in the genetic admixture.

However, if we compare the present results with those obtained with lineage-specific genetic markers, the patterns are different. After five centuries of colonization and cultural exchanges, these populations continue to maintain most of their maternal Native American gene pool ( $~ 80 \%$, García and Demarchi, 2009). In contrast, the survival of indigenous paternal lineages is extremely low $(6 \%$ and $10 \%$ in Córdoba and San Luis, respectively), due to asymmetric gene flow (García and Demarchi, 2006 and García A, 2011, Doctoral Thesis, Facultad de Ciencias Exactas, Físicas y Naturales, Universidad Nacional de Córdoba), similarly to what is practically the rule in Latin American populations (Wang et al., 2008 and literature therein). In another study, Salas et al. (2008) analyzed a 
hospital sample from the province of Córdoba using mtDNA sequences and Y-chromosome microsatellites (STRs). As expected, most of the Y-STR haplotypes observed $(97 \%)$ could be assigned to typically European lineages, whereas only a small fraction corresponded to haplotypes of likely Native American origin (2\%). But, in contrast with our results, these authors found a maternal Native American component of only $41 \%$.

These differences could be due to the source of the samples, although the different markers used also have distinct degrees of efficiency for the estimation of admixture. In this study, we worked with samples collected from relatively small rural towns (with the exception of Río Cuarto and Villa Dolores, cities with more than 10,000 inhabitants). While there is no detailed information about the origin of the samples analyzed by Salas et al. (2008), we can infer that they came from urbanized geographic areas, most likely from Córdoba city, a large, cosmopolitan capital with around 1.5 million inhabitants. Overall, the American continent is characterized by historical differences in patterns of colonization and migration, resulting in a range of different genetic contributions between rural and urban areas (Sans, 2000) and, as a rule, urbanization resulted in a greater prevalence of the European component (Avena et al., 2012).

On the other hand, similar values of African ancestry have been found in the previously mentioned studies (Martínez-Marignac et al., 2004; Seldin et al., 2007; Corach et al., 2010; Avena et al., 2012). In general, the African contribution to the gene pool of the Argentinean population is relatively low when compared to other South American countries (Brazil, Colombia, and Uruguay, for example). Our results are consistent with those of a previous study (Fejerman et al., 2005) based on autosomal markers that showed limited African admixture (2.2\%) in Buenos Aires.

A great genetic heterogeneity in the ancestral origins at the individual level was observed in Argentina by Martínez-Marignac et al. (2004), Seldin et al. (2007), Corach et al. (2010), and Avena et al. (2012). As for the differences between Córdoba and San Luis, it has to be kept in mind that the European settlement started much earlier in the province of Córdoba, the center of socio-cultural and demographic exchanges at the time of the Conquest and during the Colonial period in Argentina (Rufer, 2004). Therefore, the slightly higher percentage of European ancestry in San Luis reported by Corach et al. (2010) could be due to a larger proportion of individuals of European ancestry from the most recent migratory waves.

There is, however, another aspect to be considered: during the construction of the Argentinean Nation, governments privileged an ideological process that denied the existence of a non-European background in the country's population (Chamosa, 2008). The objective was to build "a future without memory". The mechanism employed was to replace the native population with European immigrants, but this process did not occur with the same intensity throughout Argentina. The immigration waves had less impact in the north-central and northwestern regions, which were in turn, historically, the most populated areas of the country. Although Córdoba has traditionally been regarded as one of the large "white" cities, along with Rosario and Buenos Aires (Grosso, 2008), its migration process was different from those experienced across rural areas of its province. Our results indicated the need to rethink common-sense assumptions, which generally refer to the absence or complete extinction of the Argentinean Native Americans, with a detachment of the official history from itspre-Hispanic past. And yet this past is still present in the people`s genomes.

In conclusion, the European component was the most highly represented in all 13 villages, with the Native American contribution being almost as frequent, and the African contribution reaching only about one percent. There is, however, a much higher Native American representation in the mitochondrial DNA results, reflecting the asymmetrical nature of interethnic unions occurred in the past. Yet, the most striking finding of our study was the genetic homogeneity observed among populations with different histories living across a wide territory. Some of the differences found between our results and previous reports may be due to the different types of markers used, as well as to the fact that we investigated mainly rural communities, while most of the other investigations examined urban groups, where the European genetic influence is more marked. Finally, the most general lesson learned from all this is that the complexity of the human evolutionary process defies simple explanations or easy generalizations.

\section{Acknowledgments}

We thank the subjects studied for their willingness to participate. The laboratory studies performed in Brazil were financed by Conselho Nacional de Desenvolvimento Científico e Tecnológico and Fundação de Amparo à Pesquisa do Estado do Rio Grande do Sul (Apoio a Núcleos de Excelência Program). Angelina García is a postdoctoral fellow, Maia Pauro a doctoral fellow, and Darío Demarchi a Research Career Member of the Consejo Nacional de Investigaciones Científicas y Técnicas de la República Argentina (CONICET). This investigation was also funded by the Colegio Doctoral Argentino-Brasileño Program, Ministerio de Educación, Secretaria de Políticas Universitarias, Argentina.

\section{References}

Albarracín J (2005) Inmigración en la Argentina moderna: un matrimonio en la salud y en la enfermedad con los europeos? In: Domenech EE (ed) Migraciones Contemporáneas y Diversidad Cultural en la Argentina. Centro de Estudios Avanzados de la Universidad Nacional de Córdoba, Córdoba, pp 19-40. 
Alfaro E, Dipierri JE, Gutierrez NJ and Vullo CM (2005) Genetic structure and admixture in urban populations of the NorthWest Argentina. Ann Hum Biol 32:724-737.

Amorim CEG, Gontijo CC, Falcão-Alencar G, Godinho NMO and Toledo RCP (2011) Migration in Afro-Brazilian rural communities: Crossing demographic and genetic data. Hum Biol 83:509-521.

Avena SA, Goicoechea AS, Rey JA, Agosti JC and Carnese FR (1999) Análisis de la participación del componente indígena en una muestra hospitalaria de la ciudad de Buenos Aires. Rev Arg Antr 2:211-225.

Avena SA, Goicoechea AS, Dugoujon JM, Slepoy MG, Slepoy AS and Carnese FR (2001) Análisis antropogenético de los aportes indígena y africano en muestras hospitalarias de la ciudad de Buenos Aires. Rev Arg Antr 3:79-99.

Avena SA, Goicoechea AL, Dugoujon JM, Rey JA, Dejean CB and Carnese FR (2006) Mezcla génica en una muestra poblacional de la ciudad de Buenos Aires. Medicina 66:113-118.

Avena SA, Parolin ML, Dejean CB, Ríos Part MC, Fabrikant G, Goicoechea AS, Dugoujon JM and Carnese FR (2009) Mezcla génica y linajes uniparentales en Comodoro Rivadavia (Prov. de Chubut, Argentina). Rev Arg Antr 11:25-42.

Avena S, Via M, Ziv E, Pérez-Stable EJ, Gignoux CR, Dejean C, Huntsman S, Torres-Mejía G, Dutil J, Matta JL, et al. (2012) Heterogeneity in genetic admixture across different regions of Argentina. PLoS One 7:e34695.

Batzer MA, Stoneking M, Alegria-Hartman M, Bazan H, Kass DH, Shaikh TH, Novick GE, Ioannou PA, Scheer WD and Herrera JR (1994) African origin of human-specific polymorphic Alu insertions. Proc Natl Acad Sci USA 91:1228812292.

Bobillo MC, Zimmermann B, Sala A, Huber G, Röck A, Bandelt HJ, Corach D and Parson W (2010) Amerindian mitocondrial DNA haplogroups predominate in the population of Argentina: Towards a first nationwide forensic mitocondrial DNA sequence database. Int J Legal Med 124:263-268.

Chakraborty R (1985) Gene identity in racial hybrids and estimation of admixture rates. In: Neel JV and Ahuja Y (eds) Genetic Microdifferentiation in Man and Other Animals. Indian Anthropological Association, New Delhi, pp 171-180.

Chakraborty R (1986) Gene admixture in human populations: Models and predictions. Yearb Phys Anthropol 29:1-43.

Chakraborty R and Weiss KM (1988) Admixture as a tool for finding linked genes and detecting that difference from allelic association between loci. Proc Natl Acad Sci USA 85:9119-9123.

Chamosa O (2008) Indigenous or criollo: The myth of white Argentina in Tucumán's Calchaquí Valley. Hispanic Am Histor Rev 88:71-106.

Corach D, Filgueira Risso L, Marino M, Penacino G and Sala A (2001) Routine Y-STR typing in forensic casework. Forensic Sci Int 118:131-135.

Corach D, Lao O, Bobillo C, van Der Gaag K, Zuniga S, Vermeulen M, van Duijn K, Goedbloed M, Vallone PM, Parson W, et al. (2010) Inferring continental ancestry of Argentineans from autosomal, Y-chromosomal and mitochondrial DNA. Ann Hum Genet 74:65-76.

Dean M, Stephens JC, Winkler C, Lomb DA, Ramsburg M, Boaze R, Stewart C, Charbonneau L, Goldman D, Albaugh BJ, et al. (1994) Polymorphic admixture typing in human ethnic populations. Am J Hum Genet 55:788-808.

Demarchi D, Salzano FM, Altuna M, Fiegenbaum M, Hill K, Hurtado AM, Tsunetto LT, Petzl-Erler ML and Hutz MH (2005) APOE polymorphism distribution among Native Americans and related populations. Ann Hum Biol 32:351365 .

Elizalde D and Macció G (1990) La migración interna en la Argentina. Período 1975-1980. LC/DEM G.95. Serie A-209. Celade, Santiago, 109 pp.

Excoffier L, Laval G and Schneider S (2005) Arlequin ver. 3.0: An integrated software package for population genetics data analysis. Evol Bioinform Online 1:47-50.

Fejerman L, Carnese FR, Goicoechea AS, Avena SA, Dejean CB and Ward RH (2005) African ancestry of the population of Buenos Aires. Am J Phys Anthropol 128:164-170.

García A and Demarchi DA (2006) Incidencia de linajes parentales amerindios en poblaciones del norte de Córdoba. Rev Arg Antr 8:57-72.

García A and Demarchi DA (2009) Incidence and distribution of Native American mtDNA haplogroups in Central Argentina. Hum Biol 81:59-69.

Grosso JL (2008) Indios muertos, negros invisibles. Encuentro Grupo Editor, Serie Inter/Cultura, Memoria y Patrimonio, Córdoba, $253 \mathrm{pp}$.

Kosoy R, Nassir R, Tian C, White PA, Butler LM, Silva G, Kittles R, Alarcon-Riquelme ME, Gregersen PK, Belmont JW, el al. (2009) Ancestry Informative Marker sets for determining continental origin and admixture proportions in common populations in America. Hum Mutat 30:69-78.

Mao X, Bigham AW, Mei R, Gutierrez G, Weiss KM, Brutsaert TD, Leon-Velarde F, Moore LG, Vargas E, McKeigue PM, el al. (2007) A genomewide admixture mapping panel for Hispanic/Latino populations. Am J Hum Genet 80:11711178.

Martínez-Marignac VL, Bertoni B, Parra EJ and Bianchi NO (2004) Characterization of admixture in an urban sample from Buenos Aires, Argentina, using uniparentally and biparentally inherited genetic markers. Hum Biol 76:543-557.

Morales J, Dipierri JE, Alfaro E, and Bejarano IF (2000) Distribution of the ABO system in the Argentine Northwest: Miscegenation and genetic diversity. Interciencia 25:432-435.

Pauro M, García A, Bravi MC and Demarchi DA (2010) Distribución de haplogrupos mitocondriales alóctonos en poblaciones rurales de Córdoba y San Luis. Rev Arg Antr 12:4755 .

Pellegrino A (2002) La migración internacional en América Latina. Tendencias y perfiles de los migrantes. Conferencia Hemisférica sobre Migración Internacional. CEPAL, Santiago de Chile, Chile, November 20-22.

Price AL, Patterson N, Yu F, Cox DR, Waliszewska A, McDonald GJ, Tandon A, Schirmer C, Neubauer J, Bedoya G, et al. (2007) A genomewide admixture map for Latino populations. Am J Hum Genet 80:1024-1036.

Rufer M (2004) Historias Negadas. Esclavitud, Violencia y Relaciones de Poder en Córdoba a Fines del Siglo XVIII. Ferreyra Editor, Córdoba, 217 pp.

Sala A, Penacino G and Corach D (1998) Comparison of allele frequencies of eight STR loci from Argentinean Amerindian and European populations. Hum Biol 70:937-947. 
Salas A, Jaime JC, Alvarez-Iglesias V and Carracedo A (2008) Gender bias in the multiethnic genetic composition of central Argentina. J Hum Genet 53:662-674.

Salzano FM (2002) Molecular variability in Amerindians: Widespread but uneven information. An Acad Bras Cienc 74:223-263.

Sans M (2000) Admixture studies in Latin America: From the 20th to the $21^{\text {st }}$ century. Hum Biol 72:155-177.

Santos NPC, Ribeiro-Rodrigues EM, Ribeiro-dos-Santos AK, Pereira R, Gusmão L, Amorim A, Guerreiro JF, Zago MA, Matte C, Hutz MH, et al. (2010) Assessing individual interethnic admixture and population substructure using a 48-insertion-deletion (INSEL) Ancestry-Informative Marker (AIM) panel. Hum Mutat 31:184-190.

Seldin MF, Tian C, Shigeta R, Scherbarth HR, Silva G, Belmont JW, Kittles R, Gamron S, Allevi A, Palatnik SA, et al. (2007) Argentine population genetic structure: Large variance in Amerindian contribution. Am J Phys Anthropol 132:455-462.

Serrano A (1945) Los Comechingones. Serie Aborígenes Argentinos, vol. I. Universidad Nacional de Córdoba, Córdoba, $372 \mathrm{pp}$.

Shriver MD, Parra EJ, Dios S, Bonilla C, Norton H, Jovel C, Pfaff C, Jones C, Massac A, Cameron N, et al. (2003) Skin pigmentation, biogeographical ancestry and admixture mapping. Hum Genet 112:387-399.
Shriver MD, Kennedy GC, Parra EJ, Lawson HA, Sonpar V, Huang J, Akey JM and Jones KW (2004) The genomic distribution of population substructure in four populations using 8,525 autosomal SNPs. Hum Genomics 1:274-286.

UNESCO (2005) La ruta del esclavo en el Río de la Plata: Su historia y sus consecuencias. UNESCO, Montevideo, 304 pp.

Wang S, Ray N, Rojas W, Parra M, Bedoya G, Gallo C, Poletti G, Mazzotti G, Hill K, Hurtado AM, et al. (2008) Geographic patterns of genome admixture in Latin American mestizos. PLoS Genet 4:e1000037.

Yang N, Li H, Criswell LA, Gregersen PK, Alarcon-Riquelme ME, Kittles R, Shigeta R, Silva G, Patel PI, Belmont JW, et al. (2005) Examination of ancestry and ethnic affiliation using highly informative diallelic DNA markers: Application to diverse and admixed populations and implications for clinical epidemiology and forensic medicine. Hum Genet 118:382-392

Zembrzuski VM, Basta PC, Callegari-Jacques SM, Santos RV, Coimbra CE, Salzano FM and Hutz MH (2010) Cytokine genes are associated with tuberculin skin test response in a native Brazilian population. Tuberculosis 90:44-49.

Associate Editor: Fabrício Rodrigues dos Santos

License information: This is an open-access article distributed under the terms of the Creative Commons Attribution License, which permits unrestricted use, distribution, and reproduction in any medium, provided the original work is properly cited. 